\title{
Synthesis, Characterization and Potential of Pt-Ru Supported Carbon Nanocage (CNC) Electrocatalyst for Future DMFC
}

\author{
Zatil Amali Che Ramli ${ }^{1}$, Siti Kartom Kamarudin ${ }^{1,2}$, Azran Mohd Zainoodin ${ }^{1, *}$, \\ Sahriah Basri ${ }^{1}$
}

${ }^{1}$ Fuel Cell Institute, Universiti Kebangsaan Malaysia, 43600 UKM Bangi, MALAYSIA

${ }^{2}$ Research Centre for Sustainable Process Technology, Faculty of Engineering and Built Environment, Universiti Kebangsaan Malaysia, 43600 UKM Bangi, MALAYSIA

*Corresponding Author

DOI: https://doi.org/10.30880/ijie.2019.11.07.025

Received 16 July 2019; Accepted 20 October 2019; Available online 15 November 2019

\begin{abstract}
A new type of support which is carbon nanocage (CNC) has been introduced and synthesized by pyrolysis method using $\mathrm{MgO}$ metal as the template of CNC. Three types of polymers which are PANi, PPy and PVAc have been chosen as carbon source for the CNC production that synthesized at temperature range of 600 $900{ }^{\circ} \mathrm{C}$, under $\mathrm{N}_{2}$ gas flow. All synthesized CNCs were characterized using TEM analysis to study their morphologies. From TEM characterization, the best CNC will be doped with Pt-Ru catalyst for the electrochemical test and DMFC performance. Based on XRD analysis, the estimated particle size of $\mathrm{Pt}-\mathrm{Ru} / \mathrm{CNC}$ obtained is smaller than commercial carbon black support, Pt-Ru/C. In BET analysis, the surface area of CNC support and Pt-Ru/CNC are $416 \mathrm{~m}^{2} \mathrm{~g}^{-1}$ and $154.53 \mathrm{~m}^{2} \mathrm{~g}^{-1}$ respectively, which consider a high surface area and good property as a catalyst. In electrochemical evaluation of cyclic voltammetry, the Pt-Ru/CNC electrocatalyst shows higher electrochemical surface active (ECSA) value than Pt-Ru/C, which are $16.9 \mathrm{~m}^{2} \mathrm{~g}^{-1}$ and $6.2 \mathrm{~m}^{2} \mathrm{~g}^{-1}$, respectively. This result indicates that the ECSA value of Pt-Ru/CNC 1.7 times larger than Pt-Ru/CNC. Meanwhile, from the DMFC-single cell test, the Pt-Ru/CNC with $40 \%$ (catalyst wt. \%) achieved more than $6.0 \mathrm{~mW} \mathrm{~cm}{ }^{-2}$ of power density performance, which is higher than the Pt-Ru/C. These results can be attributed to the high BET surface area of CNC support and Pt-Ru on $\mathrm{CNC}$ support. It can be concluded that Pt-Ru supported $\mathrm{CNC}$ is a superior candidate for future DMFC anode electrocatalyst.
\end{abstract}

Keywords: Carbon Nanocage; DMFC; Methanol Oxidation

\section{Introduction}

Nowadays, the renewable energy gains great attention and hot topic in energy field [1]. The fuel cell is an electrochemical device that converted the chemical energy from fuel (for example hydrogen, methanol, ethanol etc) to the electrical energy and oxidant to electricity, water and heat in the present of catalyst [2,3]. There are many types of fuel cell that have been developed such as solid oxide fuel cells (SOFC), phosphoric acid fuel cells (PAFC), molten carbonate fuel cells (MCFC) and polymer electrolyte membrane (PEM) fuel cells $[2,4]$. Each of them offers their own advantages, for example as power generation, transportation, and portable power. Direct methanol fuel cell (DMFC) is one of fuel cell type that has been gained great attention as attractive power source for mobile and portable applications due to; high energy density, simple system design, ease of handling the fuel (liquid) and operating in low temperatures $[5,6]$. Most common catalyst used for DMFC is platinum $(\mathrm{Pt})$ due to excellent catalytic activity, chemical stability, high current density exchange, and superior work function [7]. However, the high market price of Pt causes the use of Pt in electrocatalyst system must be reduced, but at the same time the catalytic performance must be excellent. Most of anode catalyst for DMFC electrode is made from Pt-based materials. However, the arising problems such as low performance, instability of catalyst, methanol crossover, and thermal and water management, were limited the

\footnotetext{
*Corresponding author: azrans@ukm.edu.my

2000 UTHM Publisher. All right reserved.

penerbit.uthm.edu.my/ojs/index.php/ijie
} 

commercialization of DMFC [8,9]. During methanol electrooxidation reaction (MOR) using Pt catalyst, the carbon monoxide (CO) as intermediates molecule will block Pt sites, that causes the surface site of Pt poisoned by CO through an indirect reaction MOR path. Hence, to avoid the Pt poisoning, binary or hybrid alloys Pt can be applied to the DMFC anode electrodes such as Pt-Ru [10], Pt-Sn [11], Pt-Mo [12], Pt-Ni 13], Pt-Fe [14] and Pt-Co [15].

In DMFC, catalyst is commonly supported on conductive and porous carbon materials. It is well known that metal catalysts with supporting materials such as carbon supports show improvement in its stability and higher catalytic performance compared to the unsupported metal catalyst. The characteristic of an ideal support should offer a good electrical conductivity, interaction of good catalyst-support, large surface area, mesoporous structure to permit the ionomer and polymer electrolyte to bring the catalyst nanoparticles near to the reactants [16]. An ideal selection of catalyst-support not only gives the good interaction between the catalyst and the support, but it can improve catalyst efficiency, reduce the catalyst loss, and enhance the durability of catalyst by reducing catalyst poisoning. Additionally, in some cases it is affecting the catalyst particle size. Hence, the behavior of chosen support material is highly influencing the performance, long life, cost of the catalyst and the overall fuel cell.

There are some approaches that have been applied to achieve better catalyst efficiency by (i) using Pt based bimetallic, ternary catalyst, and other non-precious metals to decrease the use of Pt in the electrocatalyst system [17] and; (ii) modification of the support [18,19]. Among the Pt-based bimetallic electrocatalyst, Pt-Ru alloy catalyst is commonly used as DMFC anode because of their ability to remove CO intermediate species that forms during methanol electro-oxidation [20]. As reported by Nguyen et al. 2016, highly conductive and high surface area carbon black are commonly used as Pt catalyst supports [21]. However, over the several decades, the attention has shifted towards nanostructured carbon supports such as carbon nanotube (CNT) [22], nanocoils [23], mesopores carbon(CMP) [24], carbon nanofiber (CNT) [25], and graphene [26] with excellent electrocatalytic activity in methanol oxidation reaction (MOR). The Pt-Ru supported nanocoil carbon has been synthesized using hydrothermal method showed high catalytic performance due to the combination of good electrical conductivity of their graphitic structure of carbon nanocoil and high porosity properties, which allows much less diffusional resistance of reactants/products [27]. Meanwhile, Dong et. al 2010 reported the excellent performance showed by Pt-Ru/Graphene compared to those Pt-Ru on the carbon black support, but the synthesis method need to be improved in order to obtain more uniform Pt-Ru particles size [28]. Nowadays, carbon nanocages (CNCs) with high surface area and unique properties become the newest carbon support material and potentially increase electrocatalytic activity in MOR.

The CNC support is an attractive material in many applications such as absorbent [29], catalysis [30], batteries [31], and supercapasitor [32]. On the other hand, CNC has a broad spectrum in catalytic application because of its properties such as hollow structure with graphitic shells, and high electrocatalytic activity as a catalyst support [33]. In this paper, the synthesis of CNC support from polymer source such as polyaniline (PANi), Polypyrrole (Ppy) and Poly vinyl acetate (PVac) as catalyst support has been studied. The aim of this research is to investigate method to synthesis the $\mathrm{CNC}$, followed by preparing $\mathrm{Pt}-\mathrm{Ru} / \mathrm{CNC}$ electrocatalyst. Finally, the performance of synthesized Pt-Ru/CNC electrocatalyst is evaluated in electrochemical and DMFC-single cell test.

\section{Materials and Methods}

\subsection{Preparation of CNC-support and Electrocatalyst}

In order to synthesis CNC, the source of carbon which is polyaniline (PANi), polypyrrole (PPy) and poly vinyl acetate (PVAc) must undergo polymerization process. The polymer of PANi and PPy was obtained by using chemical oxidative method [34]. Meanwhile, the polymer of PVAc was directly used by dissolving this polymer with dimethylformamide (DMF) for $1 \mathrm{~h}$ at a temperature of $600{ }^{\circ} \mathrm{C}$ and was continuously stirred for $12 \mathrm{hrs}$ [35]. After that, the $\mathrm{MgO}$ metal as template for the formation of hollow cage is added to the polymer (e.g. PANi) solution and stirred for $60 \mathrm{~min}$ to ensure all metal particles are well mixed with polymer solution [36]. Then, the mixture is peel-off and allow for pyrolysis at three operating temperatures $600{ }^{\circ} \mathrm{C}, 750^{\circ} \mathrm{C}$ and $900{ }^{\circ} \mathrm{C}$ for each $\mathrm{CNC}$ source. Pyrolysis is runned in the tube furnace under $\mathrm{N}_{2}$ gas flow for 2 hrs. After two hours, the carbon support is taken out and allowed to cooled at room temperature before proceed with the acid leaching process. $1 \mathrm{M} \mathrm{HNO}_{3}$ is mixed to the as-grown samples and stirred for $6 \mathrm{hrs}$ to remove the $\mathrm{MgO}$ templates. Finally, the samples were washed with ethanol solution and deionized water (DI) until neutral $\mathrm{pH}$ and dried in oven for $6 \mathrm{hrs}$ at $100^{\circ} \mathrm{C}$. The experiment is repeated for the preparation of CNC using PPy and PVAc sources with similar experiment conditions. All electrocatalyst are synthesized using alcohol reduction method assisted with microwave technique.

In this study, the best CNC support will be chosen to be doped with Pt-Ru catalyst. $40 \mathrm{wt} \%$ of Pt-Ru with the atomic ratio 3:1 is loaded onto CNC support. Firstly, chloroplatinic acid (Pt source), and ruthenium chloride (Ru source) precursors are mixed with Ethylene Glycol (EG) solutions (70:30/EG:DI in v/v) and sonicated for $15 \mathrm{~min}$. Then, both precursor solution was added into the synthesized-CNC powder and stirred for $30 \mathrm{~min}$ and to make well mixed. Then, the $\mathrm{pH}$ of the solution was adjusted to 10 using $1 \mathrm{M} \mathrm{NaOH}$ solution. Furthermore, the mixture was heated using microwaves for $1 \mathrm{~min}$ and off for $1 \mathrm{~min}$ twice to allow completion of the reduction process Lastly, the sample was filtered and washed with ethanol and DI water several times before dried in oven for $120^{\circ} \mathrm{C}$ for $3 \mathrm{hrs}$. 


\subsection{Characterizations}

For the characterizations purpose, Transmission Electron Microscopy (TEM), JEM-1010 JEOL with $100 \mathrm{kV}$ and Field Emission Scanning Electron Microscope (FESEM) analysis were applied to investigate the surface morphology and the shapes of the samples. X-Ray Diffraction (XRD) is a powerful physical characterization to show crystallinity of the synthesized samples. All the synthesized samples were analyzed at $2 \theta$ from $5^{\circ}$ to $100{ }^{\circ}$ by using D8 Advance/Bruker, AXS Germany model. Analysis of Branauer, Emmett and Teller (BET) and nitrogen adsorptiondesorption isotherm plot was carried at $-196.15{ }^{\circ} \mathrm{C}$ by using Micromeritics ASAP 2020 to obtain the surface area and pore properties of the samples. Meanwhile, Raman spectrum analysis was applied to describe the degree of graphitization.

\subsection{Electrochemical Characterization and Performance Test}

The measurement of electrochemical surface area (ECSA) for the synthesized electrocatalyst was measured using the cyclic voltammetry $(\mathrm{CV})$ in acid medium $\left(0.5 \mathrm{M} \mathrm{H}_{2} \mathrm{SO}_{4}\right)$. Three electrode cell system involved which are platinum as the counter electrode, glassy carbon electrode $(3 \mathrm{~mm} \varnothing)$ as the working electrode and $\mathrm{Ag} / \mathrm{AgCl}$ electrodes as the reference electrodes, respectively, operated at room temperature. The electrocatalyst ink for working electrode is prepared by dispersing $3 \mathrm{mg}$ of electrocatalyst in a mixture of $130 \mu \mathrm{L}$ DI water, $130 \mu \mathrm{L}$ IPA and $55 \mu \mathrm{L}$ Nafion solution (5 wt \%). The catalyst loading on the glassy electrode was $0.0673 \mathrm{mg} \mathrm{cm}$. The $\mathrm{CV}$ measurement was performed at a scan rate of $50 \mathrm{mV} \mathrm{s}^{-1}$, and the potentials range of -0.3 to $1.2 \mathrm{~V}$ vs. Ag/AgCl. The DMFC-single cell test was carried out in passive mood. The preparation of DMFC single cell was done by method used by [37]. The catalyst loading on the MEA size $4 \mathrm{~cm}^{2}$ is $2.0 \mathrm{mg} \mathrm{cm}$.

\section{Results and Discussion}

\subsection{Materials Characterization}

Figure 1 shows the synthesis of CNC support using pyrolysis method. The operating temperature used to obtain the $\mathrm{CNC}$ is range of $600-900{ }^{\circ} \mathrm{C}$ in which at temperature of $600{ }^{\circ} \mathrm{C}$ considered as lowest operating temperature, $750{ }^{\circ} \mathrm{C}$ was moderate temperature while $900^{\circ} \mathrm{C}$ considered as the highest operating temperature.

(a)

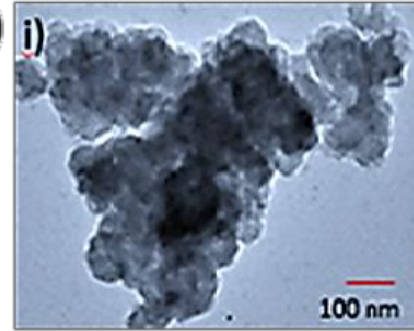

(b) i)

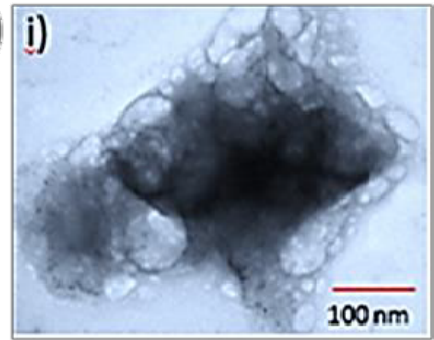

(c)

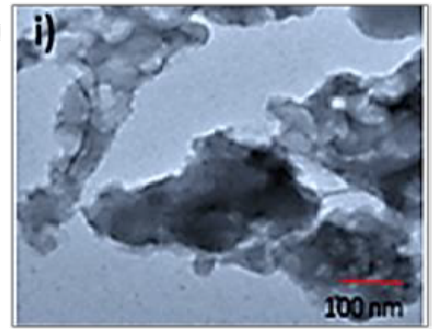

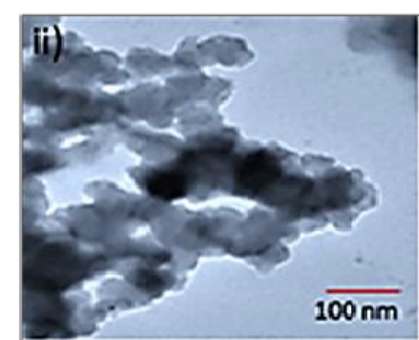
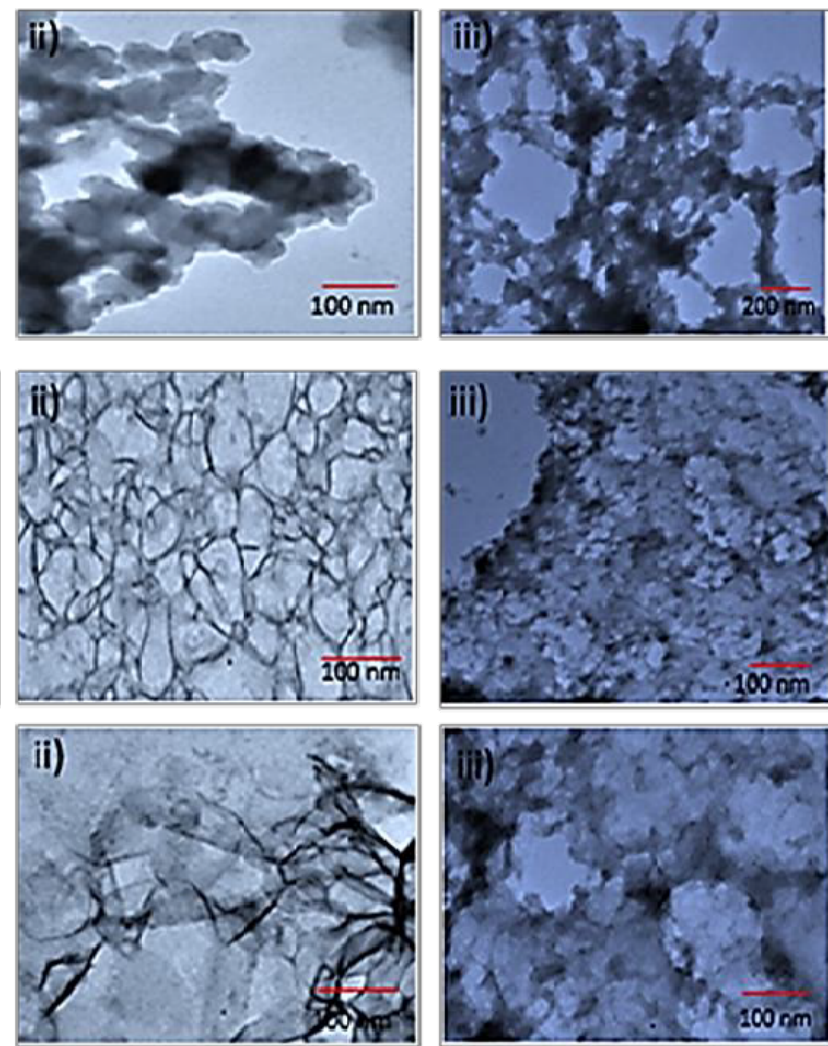
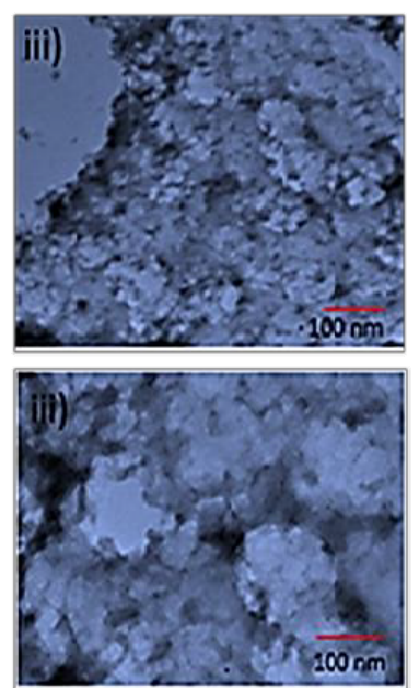

Fig. 1 - TEM images for CNC prepared from different operating temperature pyrolysis at (a) $600{ }^{\circ} \mathrm{C}$, (b) 750 ${ }^{\circ} \mathrm{C}$ and (c) $900{ }^{\circ} \mathrm{C}$ for source from (i) PANi, (ii) PPy and (iii) PVAc, respectively 
Generally, CNC support can be produced within this operating temperature range. However, it may be depending on the type of carbon source used to produce the $\mathrm{CNC}$ equipped suitable method. Sometimes, the operating temperature could be very high to obtain uniform shape and better CNC morphology [22]. There are several methods can be used to obtain the CNC support, but in this investigation the pyrolysis of carbon containing $\mathrm{MgO}$ metals (as cage template) was chosen because of the simpler and easy route for the CNC production. Regarding to the TEM analysis, the CNC that synthesized from PPy at temperature $750{ }^{\circ} \mathrm{C}$ is selected as the best $\mathrm{CNC}$ support, based on the successful formation of hollow structure in the middle of the carbon material as shown in figure $1 \mathrm{~b}$ (ii). Besides that, the thick ring shape can also be seen in TEM image, as the proven of the carbon cage shape [33]. But, the lattice structure of CNC cannot clearly be seen in the TEM because of limitation of the instrument, which is normally be observed clearly under high resolution TEM [38]. Moreover, from the TEM analysis obtained in this work, it can be said that some improvement should be done in methodology aspect must to get shape and more uniform size of CNC.

Meanwhile, the production of CNC from PANi source at temperature $750{ }^{\circ} \mathrm{C}$, the formation of carbon cage started to form but still in very poor crystallization. As known, there are many methods have been developed to produce $\mathrm{CNC}$ support such as spray pyrolysis iron carbonyl and carbon precursor [22]. By changing the of pyrolysis temperature, the graphitization of the carbon also varied. Meanwhile, at highest temperature $\left(900{ }^{\circ} \mathrm{C}\right)$ the $\mathrm{CNC}$ observed from the same source already broken out. Meanwhile, the carbon support prepared from PVAc source with same temperature, it can be concluded that other method should be applied to get successful carbon cage formation.

Figure 2 shows the XRD analysis for sample named, CNC support synthesized by pyrolysis of PPy at temperature $750{ }^{\circ} \mathrm{C}$. While, the $\mathrm{Pt}-\mathrm{Ru} / \mathrm{CNC}$ and $\mathrm{Pt}-\mathrm{Ru} / \mathrm{C}$ commercial were synthesized by microwaved-assisted alcohol-reduction method [39]. From XRD analysis for CNC support sample, the clearly peak can be seen at plane (002) and (100) at 2 theta $26.6^{\circ}$ and $43^{\circ}$, respectively, which corresponded to the diffraction peaks of graphite formation in CNC support [29]. In the XRD pattern, a broad diffraction peak can also be seen clearly observed at $20^{\circ}-30^{\circ}$ indicating the low crystalline or disordered carbon was form in this experiment. This result also close to the result reported by Li et. al [29]. The CNC-PPy pyrolysis at $750{ }^{\circ} \mathrm{C}$ is selected as the best synthesized CNC among them and has been doped with $\mathrm{Pt}-\mathrm{Ru}$ catalyst. The XRD results for synthesized Pt-Ru/CNC shows the presence of all particles, Pt-Ru, and $\mathrm{C}$ support. The Pt nanoparticle was detected by diffraction peaks at plane $\left(\begin{array}{lll}1 & 1 & 1\end{array}\right),\left(\begin{array}{lll}2 & 0 & 0\end{array}\right)$, and $\left(\begin{array}{lll}2 & 2 & 0\end{array}\right)$ at approximately 2 theta $41.4^{\circ}, 48.5^{\circ}$ and $68^{\circ}$, respectively which consistent with the face-centered cubic (fcc) structure of Pt [40]. However, the low diffraction peaks of CNC difficult to be observed after dispersion of Pt-Ru particles on the CNC support because of high crystallinity of Pt-Ru nanoparticles in the electrocatalyst system. Only a single diffraction peaks of Pt-Ru can be observed in the XRD pattern, indicating that the successful formation of alloy or bimetallic formation of Pt-Ru in both type of electrocatalysts [41]. Besides that, the estimated crystallite size of Pt-Ru was calculated by using Scherrer's equation that showed the smaller particle size of $\mathrm{Pt}-\mathrm{Ru} / \mathrm{CNC}$ than those $\mathrm{Pt}-\mathrm{Ru} / \mathrm{C}$ [35]. The crystallite size obtained can also be used to estimate the particle size of $\mathrm{Pt}$ and $\mathrm{Ru}$ as presented in Table 1. Generally, in electrocatalysis reaction the smaller particle gives better performance in MOR compared to large particle size, because the smaller size of catalyst particles contributes to the higher surface site of particle. In addition, the smaller catalyst particle size can give advantage to reduce the usage of Pt in electrocatalyst, and furthermore the overall cost of DMFC production. The lower crystalline structure could also be related to the smaller size of $\mathrm{Pt}-\mathrm{Ru}$ particle obtained in the electrocatalyst sample [42].

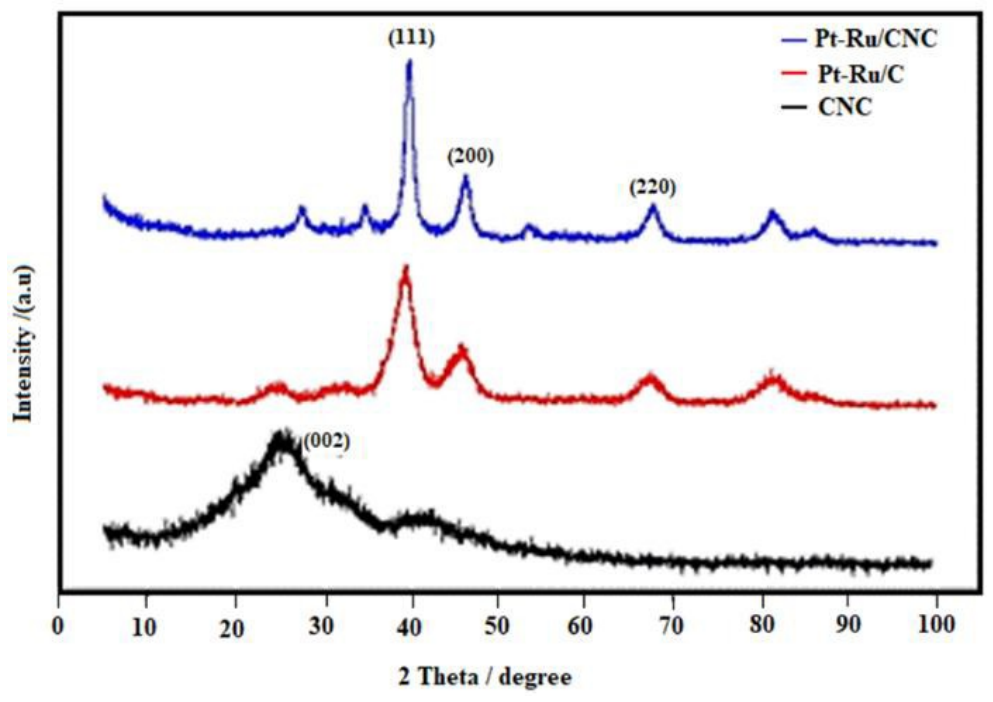

Fig. 2 - XRD patterns for prepared samples. 
Table 1 - Particle size properties by XRD

\begin{tabular}{lc}
\hline Catalysts & XRD crystallite size (nm) \\
\hline $\mathrm{Pt}-\mathrm{Ru} / \mathrm{CNC}$ & 3.2 \\
$\mathrm{Pt}-\mathrm{Ru} / \mathrm{C}$ & 3.5 \\
\hline
\end{tabular}

Raman spectroscopy analysis was carried out to observe vibrational, rotational and other low frequency modes in a sample. This technique is commonly used to provide a structural fingerprint by which molecules can be identified. For the sample contain carbon material two band namely D band and G band will arise during measurement [43]. As shown in Figure 3 for all prepared samples, D band at approximately $1340-1358 \mathrm{~cm}^{-1}$ and a $\mathrm{G}$ band at $1578-1596 \mathrm{~cm}^{-1}$, corresponds to the existence of poly-crystalline graphite [44]. The D band is corresponded to the vibration mode of carbon atoms with dangling bonds in plane terminations of disorder graphite. While $\mathrm{G}$ band is referred to the vibration modes of sp2 hybridized carbon atoms in the graphitic layer [45]. Usually, the value of D band and $\mathrm{G}$ band ratio $\left(\mathrm{I}_{\mathrm{D}} / \mathrm{I}_{\mathrm{G}}\right)$ can be calculated to describe the reflects of graphitization degree. In this experiment, the value of $\mathrm{CNC}$ and $\mathrm{Pt}-\mathrm{Ru} / \mathrm{CNC}$ are; 1.01 and 1.16, respectively. The greater the value of $\left(\mathrm{I}_{\mathrm{D}} / \mathrm{I}_{\mathrm{G}}\right)$, indicates the higher the defects of graphite [46]. However, in this case only slight increment in $\mathrm{I}_{\mathrm{D}} / \mathrm{I}_{\mathrm{G}}$ value for $\mathrm{Pt}-\mathrm{Ru} / \mathrm{CNC}$ electrocatalyst was observed. That is meant the defect/disorder of graphite in the sample is very small. This situation can also be related to the addition of the Pt-Ru metal that may slightly affected the carbon structure.

Figure 4 shows FESEM images for the Pt-Ru/CNC and Pt-Ru/C prepared by microwave-assisted alcohol-reduction of method. The images clearly indicate that these carbons supporting materials are in spherical shape [42]. The result shows that both samples were agglomerated with an approximate diameter size is between 120-150 nm which is in nanoscale size. The agglomeration may be caused of Van der Waals bond within particles [47]. Unfortunately, the bimetallic catalyst cannot easily be seen on the FESEM image because of it very tine appearance as synthesized catalyst, which generally produced in range of $2-5 \mathrm{~nm}$ scale $[5,48]$. No obvious difference can be observed in samples morphological for the both electrocatalyst using FESEM image.

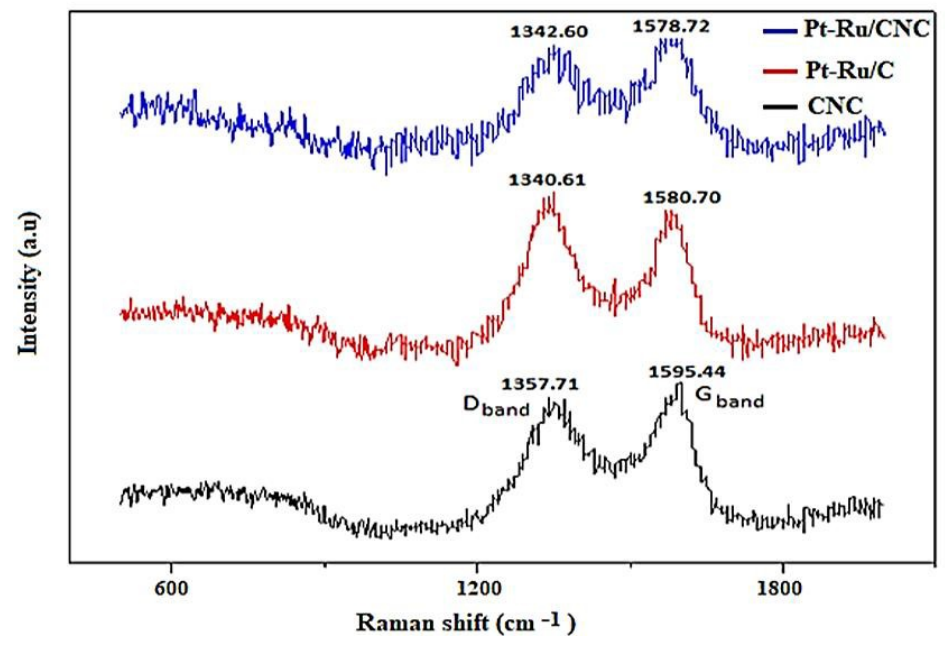

Fig. 3 - Raman spectroscopy analysis of the prepared (a) CNC, (b)Pt-Ru/CNC and

(C) Pt-Ru/C
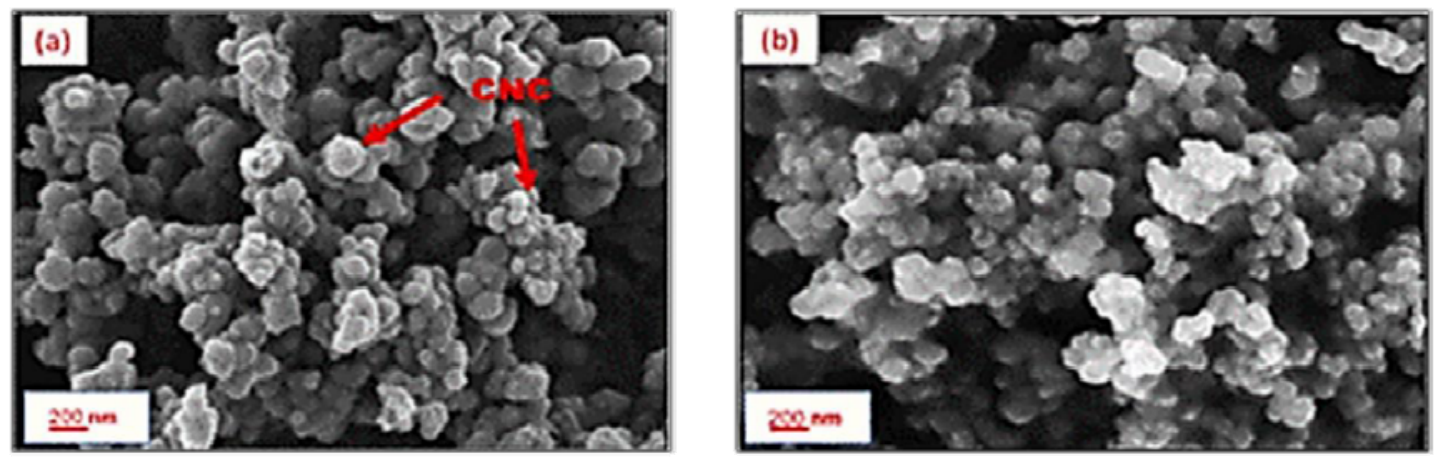

Fig. 4 - FESEM images of the prepared (a) Pt-Ru/CNC and (b) Pt-Ru/C. 

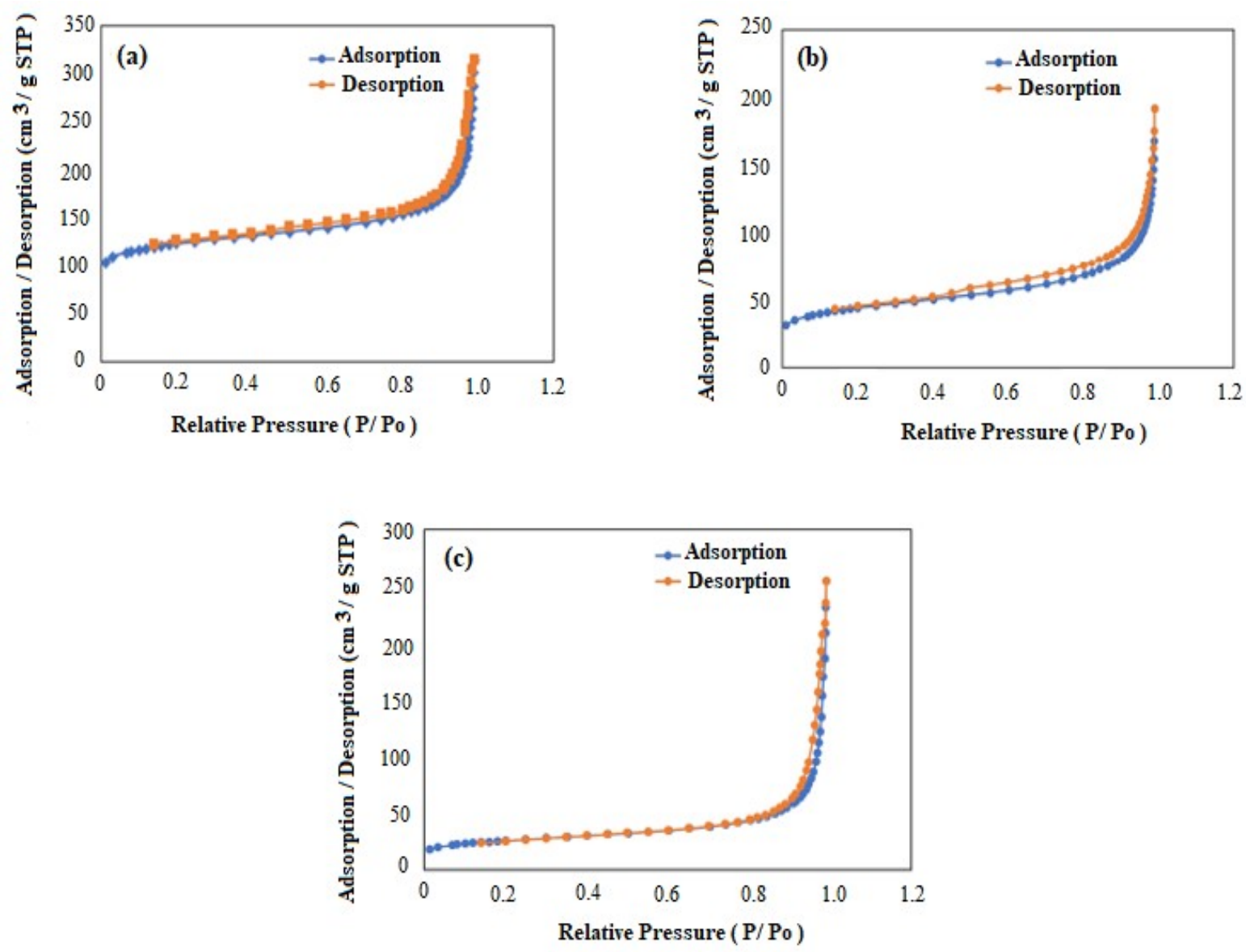

Fig. 5 - Isotherms adsorption/desorption curve for (a) CNC support, (b) Pt-Ru/CNC and (c) Pt-Ru/C runned at $-196.15{ }^{\circ} \mathrm{C}$ under nitrogen gas flow.

The nitrogen adsorption/desorption linear isotherm are measured at temperature $-196.15{ }^{\circ} \mathrm{C}$ under nitrogen gas flow to evaluate the specific surface area and porosity properties of sample. The isotherm linear adsorption/desorption graph were also depicted in Figure 5. From BET analysis, the specific surface area $\left(\mathrm{S}_{B E T}\right)$ of CNC support is $416 \mathrm{~m}^{2} \mathrm{~g}^{-1}$, which is larger than CNC synthesized from ethanol, cyclohexane and PEG as reported [29]. However, the $\mathrm{S}_{B E T}$ decreased after dispersed of catalyst metal on CNC support but, the $\mathrm{S}_{\mathrm{BET}}$ of Pt-Ru/CNC electrocatalyst still showed higher value than Pt-Ru/C. The decreased of BET specific surface area of Pt-Ru/CNC after dispersion of Pt-Ru metals on CNC support indicates that the catalyst metal was successfully deposited onto the surface of CNC support $[42,49]$. This is also due to the present of Pt-Ru catalyst particles onto the CNC support that blocks some micropores which then leads to the decreased of BET specific surface area [35]. On the other hand, the prepared electrocatalyst showed the pore size was in mesopores size in range of 5.6-39.3 nm. The mesopores size has advantage which demonstrates good morphology stability and could increase the level of distribution and homogeneity of the immobilized catalyst, resulting improving in stability and catalytic activity due to increase of adsorption volume [50]. The smaller pore volume of Pt$\mathrm{Ru} / \mathrm{CNC}$ electrocatalyst compared to their CNC support, due to some porous space in carbon cages support media was blocked with catalyst particles or may other chemical reaction take place during the process of nanoparticle decoration and, subsequently resulted in the decrease of the pore volume. In addition, the isotherm curve in this study observed the $\mathrm{Pt}-\mathrm{Ru} / \mathrm{CNC}$ and $\mathrm{Pt}-\mathrm{Ru} / \mathrm{C}$ are found in mesoporous properties, which have an average diameter within the range of 2-50 $\mathrm{nm}$, which can largely be attributed to the large gap found in the electrocatalyst lattice. Meanwhile, Table 2 shows the porosity properties of the prepared samples. All prepared samples show mesopore type which has ability to increase the level of distribution and homogeneity of the immobilized catalyst, resulting in improving stability and catalytic activity [51]. 
Table 2 - Electrocatalyst properties of the samples

\begin{tabular}{lccc}
\hline Electrocatalysts Properties & CNC support & Pt-Ru/CNC & Pt-Ru/C \\
\hline Surface area $\left(\mathrm{m}^{2} \mathrm{~g}^{-1}\right)$ & 416.00 & 154.53 & 90.00 \\
Pore volume $\left(\mathrm{cm}^{3} \mathrm{~g}^{-1}\right)$ & 0.49 & 0.03 & 0.01 \\
Pore size $(\mathrm{nm})$ & 39.20 & 5.60 & 12.90 \\
Type of pore & Mesopore & Mesopore & Mesopore \\
\hline
\end{tabular}

\subsection{Electrochemical Evaluation}

Figure 6 represents the $\mathrm{CV}$ profile for $\mathrm{Pt}-\mathrm{Ru} / \mathrm{CNC}$ and $\mathrm{Pt}-\mathrm{Ru} / \mathrm{C}$ carried out in $0.5 \mathrm{M}$ sulphuric acid at potential range -0.3 to $1.2 \mathrm{~V}$ vs. $\mathrm{Ag} / \mathrm{AgCl}$ using cyclic voltammetry $(\mathrm{CV})$. The $\mathrm{CV}$ profile classify three potential ranges that can be notable as; (i) hydrogen adsorption/desorption region, (ii) surface oxide formation/reduction region and (iii) double layer legion region/faradic [52]. From the CV profile the adsorption/desorption of hydrogen can be determined by the appearance of peaks at range -0.2 to $1.0 \mathrm{~V}$. Meanwhile, the value of electrochemical surface active (ECSA) can be determined through calculation using equation below:

$$
E C S A=\frac{q P t}{\Gamma . L}
$$

Where, charge density $\mathrm{q}_{\mathrm{Pt}}$ obtained from $\mathrm{CV}$ graph, $\Gamma=210 \mu \mathrm{C} \mathrm{cm}^{-2} \mathrm{Pt}$, and $L$ is the Pt loading in the electrode. Table 3 shows the ECSA values for the electrocatalyst for the comparison purpose. From the table, the ECSA value for $\mathrm{Pt}-\mathrm{Ru} / \mathrm{CNC}$ is larger than $\mathrm{Pt}-\mathrm{Ru} / \mathrm{C}$. Hence, it can be act as ideal candidate for the MOR and DMFC performance. This result can also predict the high performance of $\mathrm{Pt}-\mathrm{Ru} / \mathrm{CNC}$ in $\mathrm{MOR}$ and DMFC single cell test.

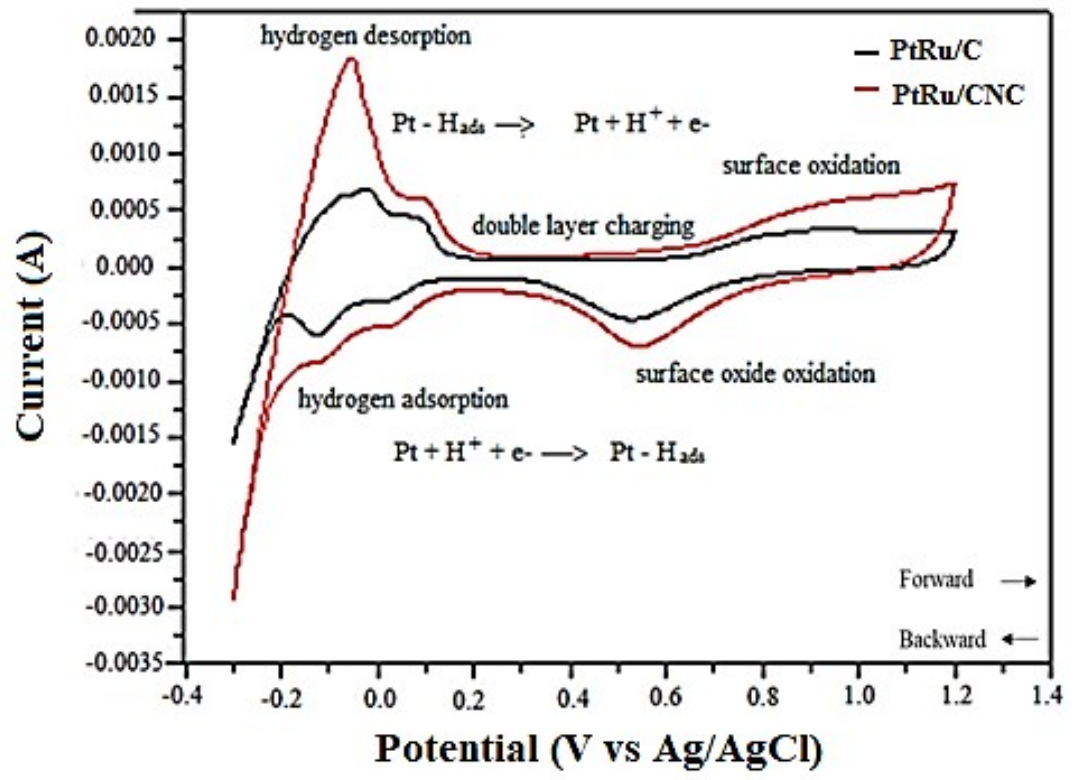

Fig. 6 - CV profile for Pt-Ru/CNC and Pt-Ru/C carried out in $0.5 \mathrm{M} \mathrm{H}_{2} \mathrm{SO}_{4}$, at scanning rate $50 \mathrm{mV} \mathrm{s}^{-1}$

Table 3 - ECSA values for the electrocatalysts

\begin{tabular}{lcc}
\hline Catalysts & Catalyst loading (\%) & ESCA value $\left(\mathbf{m}^{2} \mathbf{g}^{-1}\right)$ \\
\hline $\mathrm{Pt}-\mathrm{Ru} / \mathrm{CNC}$ & 4 & 16 \\
$\mathrm{Pt}-\mathrm{Ru} / \mathrm{C}$ & 4 & 6 \\
\hline
\end{tabular}


The Pt-Ru/CNC is tested in passive mood of DMFC single cell in $2.0 \mathrm{M} \mathrm{CH}_{3} \mathrm{OH}$ to evaluate the potential of Pt-Ru supported CNC support, as presented in Fig.7. The performance of Pt-Ru/CNC electrocatalyst shows highly improved in electrooxidation of methanol with power density achieved more than $6.0 \mathrm{~mW} \mathrm{~cm}{ }^{-2}$. The obtained result was also higher than Pt-Ru supported carbon black reported by Tang et al. [53] Shimazu et al.[54] and Hashim et al. [55], which achieved the DMFC performance of $1.7 \mathrm{~mW} \mathrm{~cm}^{-2}, 3.0 \mathrm{~mW} \mathrm{~cm}^{-2}$ and $3.3 \mathrm{~mW} \mathrm{~cm}^{-2}$, respectively. This excellent performance can be related to the large $S_{B E T}$ and high ECSA value in CV profile. Lastly, we can summarise that the bimetallic catalyst of Pt-Ru supported carbon nanocage (CNC) can be used as ideal candidate for anodic DMFC.

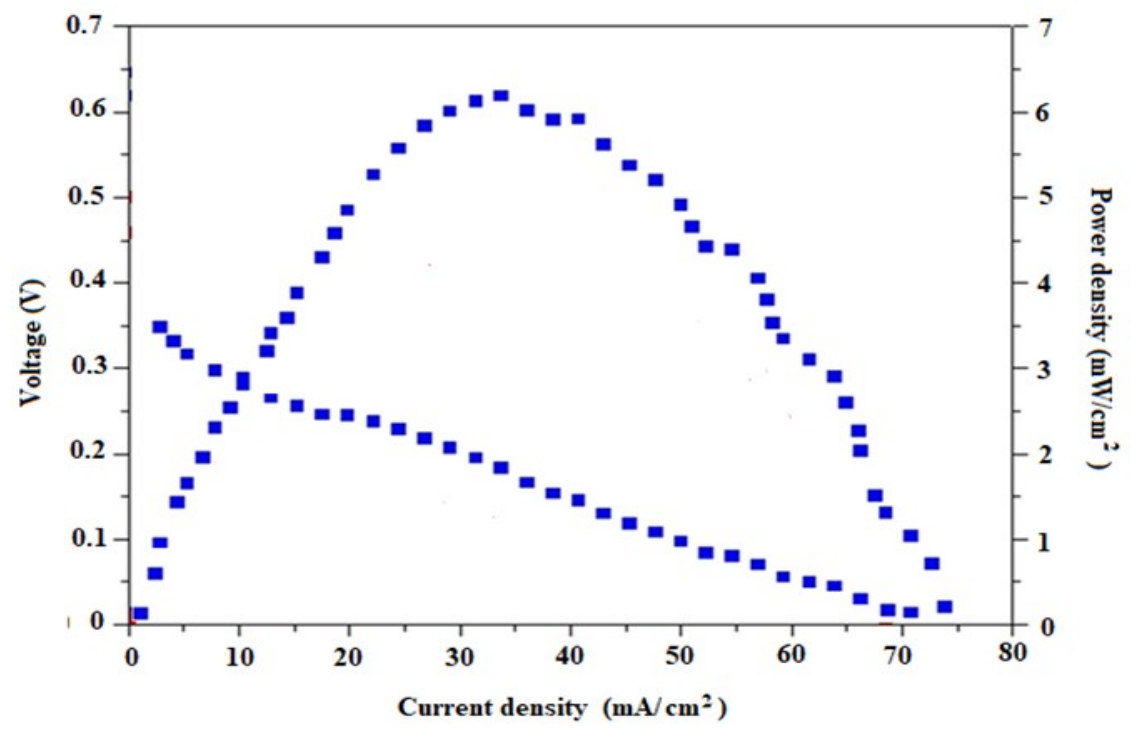

Fig. 7- I-V polarization curve for Pt-Ru/CNC carried out in $2.0 \mathrm{M} \mathrm{CH}$

\subsection{Conclusion}

In this work, the CNC support from PPy source at operating temperature $750{ }^{\circ} \mathrm{C}$ successfully synthesized by pyrolysis using $\mathrm{MgO}$ metal template, followed by the preparation of $\mathrm{Pt}-\mathrm{Ru} / \mathrm{CNC}$ electrocatalyst from the best $\mathrm{CNC}$ (PPy-750) by using simple method of microwave assisted alcohol-reduction. The synthesis of CNC-PPy using metal template $(\mathrm{MgO})$ has not been reported yet. From BET analysis, CNC demonstrated large surface area which is $416 \mathrm{~m}^{2}$ $\mathrm{g}^{-1}$ which is good property as catalyst supporting material. The Pt-Ru/CNC electrocatalyst also showed more than 2.7 times higher ECSA value than $\mathrm{Pt}-\mathrm{Ru} / \mathrm{C}$ which is $16.9 \mathrm{~m}^{2} \mathrm{~g}^{-1}$ and $6.2 \mathrm{~m}^{2} \mathrm{~g}^{-1}$, respectively. This result suggested to give higher electrocatalytic performance in methanol oxidation of DMFC test. Moreover, the DMFC single cell test showed excellent power density which is more than $6.0 \mathrm{~mW} \mathrm{~cm}^{-2}$, which is higher than $\mathrm{Pt}-\mathrm{Ru} / \mathrm{C}$ reported by others group. This superior performance can be attributed to the large surface area belongs to CNC and high ECSA value from its characterization. Lastly, it can be concluded that from characterizations and electrochemical testing, the CNC and Pt$\mathrm{Ru} / \mathrm{CNC}$ electrocatalyst possess high potential to be an ideal candidate for the future MOR and DMFC electrocatalyst. However, several studies must be further carried out in details as extra information to support the factors catalytic contribute to the higher catalytic performance of Pt-Ru supported CNC support.

\section{Acknowledgement}

The authors gratefully acknowledge the financial support given by Universiti Kebangsaan Malaysia under the grant the GGPM-2018-057.

\section{References}

[1] Aman, N. A. M. N., Muchtar, A., Somalu, M. R., Rosli M. I., Baharuddin N. A., Kalib N. S. (2018). A short review on the modeling of solid-oxide fuel cells by using computational fluid dynamics: assumptions and boundary conditions. International Journal of Integrated Engineering, 10(5), 87-92.

[2] Yamamoto, T., Ishimaru, K., Osman, K., Kori, M. I., Khudzari, A. Z., Taib, I., Yamamoto, T. (2018). Numerical Simulation of Concentration Over-voltage in a Polymer Electrolyte Fuel Cell under Low-Hydrogen Condition. International Journal of Integrated Engineering, 10(4), 88-94.

[3] Sharma, S., \& Pollet, B. G. (2012). Support Materials for PEMFC and DMFC Electrocatalysts-A Review. Journal of Power Sources, 208, 96-119.

[4] Ebshish, A., Yaakob, Z., Narayanan, B., Bshish, A., \& Daud, W. R. W. (2011). The activity of Ni-based catalysts on steam reforming of glycerol for hydrogen production. International Journal of Integrated Engineering, 3, 5-8. 
[5] Ramli, Z. A. C., \& Kamarudin, S. K. (2018). Platinum-Based Catalysts on Various Carbon Supports and Conducting Polymers for Direct Methanol Fuel Cell Applications: A Review. Nanoscale Research Letters, 13, 410.

[6] Ahmad, M. M., Kamarudin, S. K., Daud, W. R. W., \& Yaakub, Z. (2010). High Power Passive $\mu$ DMFC with Low Catalyst Loading for Small Power Generation. Energy Conversion and Management, 51(4), 821-825.

[7] Cong, H., Ren, X., \& Yu, S. (2012). Controlled Synthesis of Pt-Ru/Graphene Nanocatalysts with Enhanced Methanol Oxidation Activity for Fuel Cells. ChemCatChem, 4(10), 1555-1559.

[8] Kamarudin, S. K., Achmad, F., \& Daud, W. R W. (2009). Overview on the Application of Direct Methanol Fuel Cell (DMFC) for Portable Electronic Devices. International Journal of Hydrogen Energy, 34(16), 6902-6916.

[9] Sharaf, O. Z., \& Orhan, M. F. (2014). An Overview of Fuel Cell Technology: Fundamentals and Applications. Renewable and Sustainable Energy Reviews, 32, 810-853.

[10] Yu, X., Zhang, Q., Ling, Y., Yang, Z., \& Cheng, H. (2018). Promoted Stability and Electrocatalytic Activity of Pt-Ru Electrocatalyst Derived from Coating by Cerium Oxide with High Oxygen Storage Capacity. Applied Surface Science, 455, 815-820.

[11] Li, H., Chen, S., Li, Q., \& Liu, F. (2016). Effect of The pH of The Preparation Medium On The Microstructure And Electrocatalytic Activity of Carbon Nanotubes Decorated With PtSn Nanoparticles For Use In Methanol Oxidation. New Carbon Mater., 31(3), 293-300.

[12] Elbaz, L., Kreller, C. R., Henson, N. J., \& Brosha, E. L. (2014). Electrocatalysis of Oxygen Reduction With Platinum Supported On Molybdenum Carbide-Carbon Composite. J. Electroanal. Chem., (720-721), 34-40.

[13] Zhou, Y.-Y., Liu, C.-H., Liu, J., Cai, X.-L., Lu, Y., Zhang, H., Sun, X.-H., \& Wang, S.-D. (2016). SelfDecoration of PtNi Alloy Nanoparticles on Multiwalled Carbon Nanotubes for Highly Efficient Methanol Electro-Oxidation. Nano-micro Lett., 8(4), 371-380.

[14] Te Hung, C., Liou, Z. H., Veerakumar, P., Wu, P. H., Liu, T. C., \& Bin, L. S. (2016). Ordered Mesoporous Carbon Supported Bifunctional PtM (M $=\mathrm{Ru}$, Fe, Mo) Electrocatalysts For a Fuel Cell Anode. Cuihua Xuebao/Chinese J. Catal., 37(1), 43-53.

[15] Huang, H., Sun, H., \& Wang, X. (2012). PtCo Alloy Nanoparticles Supported On Graphene Nanosheets With High Performance For Methanol Mxidation. Chinese Sci. Bull., 57(23), 3071-3079.

[16] Jha, N., Reddy, A. L. M., Shaijumon, M. M., Rajalakshmi, N., \& Ramaprabhu, S. (2008). Pt-Ru/Multi-Walled Carbon Nanotubes as Electrocatalysts for Direct Methanol Fuel Cell. International Journal of Hydrogen Energy, 33(1), 427-433.

[17] Basri, S., Kamarudin, S. K., Daud, W. R. W., Yaakob, Z. \& Kadhum, A. A. H. (2014). Novel Anode Catalyst for Direct Methanol Fuel Cells. The Scientific World Journal, 2014, 547-604.

[18] Sha, R., Jones, S. S., \& Badhulika, S. (2019). Controlled Synthesis of Platinum Nanoflowers Supported on Carbon Quantum Dots as a Highly Effective Catalyst for Methanol Electro-Oxidation. Surface and Coatings Technology. 360, 400-408

[19] Tu, W., Sun, Y., Wu, D., Wang, H., Huang, H., Shao, M., Liu, Y., \& Kang, Z. (2019). Cobalt Oxyhydroxide and Carbon Dots Modified by Platinum as Superior Electrocatalyst for Methanol Oxidation. Materials Chemistry and Physics, 225, 64-71.

[20] Wang, Y., Yang, S., Li, S., Tien, H., Hsiao, S., Liao, W., Liu, C., Chang, K., Ma, C. M., \& Hu, C. (2013). Threedimensionally Porous Graphene-Carbon Nanotube Composite-supported Pt-Ru Catalysts with an Ultrahigh Electrocatalytic Activity for Methanol Oxidation. Electrochimica Acta, 87, 261-269.

[21] Nguyen, P. P. T., Ngo, M. H. , Ngo, L. T., \& Nguyen, T. C. M. (2012). Synthesis of Platin/Carbon XC72R Nanocomposite Using as Electrocatalyst For Direct Methanol Fuel Cells. J. Chem. Chem. Eng. 6(6), 925-929.

[22] Sebastián, D., Suelves, I., Pastor, E., Moliner, R., \& Lázaro, M. J. (2013). The Effect of Carbon Nanofiber Properties as Support For Pt-Ru Nanoparticles On The Electrooxidation Of Alcohols. Appl. Catal. B Environ., (132-133), 13-21.

[23] Celorrio, V., Flórez-Montaño, J., Moliner, R., Pastor, E., \& Lázaro, M. J. (2014). Fuel Cell Performance of Pt Electrocatalysts Supported On Carbon Nanocoils. International Journal of Hydrogen Energy, 39(10), 5371-5377.

[24] Tesfu-Zeru, T., Sakthivel, M., \& Drillet, J.-F. (2017). Investigation of Mesoporous Carbon Hollow Spheres as Catalyst Support in DMFC Cathode. Appl. Catal. B Environ., 204, 173-184.

[25] Nassr, A. B. A. A., Sinev, I., Grünert, W., \& Bron, M. (2013). PtNi Supported On Oxygen Functionalized Carbon Nanotubes: In Depth Structural Characterization And Activity For Methanol Electrooxidation. Appl. Catal. B Environ., 142-143, 849-860.

[26] Dong, L., Reddy, R., Gari, S., Li, Z., Craig, M. M., \& Hou, S. (2009). Graphene-supported Platinum and Platinum-Ruthenium Nanoparticles With High Electrocatalytic Ectivity For Methanol And Ethanol Oxidation. Carbon N. Y., 48(3), 781-787.

[27] Sevilla, M., Lota, G., \& Fuertes, A. B. (2007). Saccharide-based Graphitic Carbon Nanocoils as Supports For PtRu Nanoparticles For Methanol Electrooxidation. Journal of Power Sources, 171(2), 546-551.

[28] Dong, L., Liu, Q., Wang, L., \& Chen, K. (2011). Graphene-Supported Platinum and Platinum-Ruthenium Nanoparticles for Fuel Cell Applications. Physics and Applications of Graphene-Experiments, Dr. Sergey 
Mikhailov (Ed.), InTech, ISBN: 978-953-307-217-3.

[29] Li, G., Yu, H., Xu, L., Ma, Q., Chen, C., Hao, Q., \& Qian, Y. (2011). General Synthesis of Carbon Nanocages And Their Adsorption of Toxic Compounds From Cigarette Smoke. Nanoscale, 3(8), 3251-3257.

[30] Wang, X. X., Tan, Z. H., Zeng, M., \& Wang, J. N. (2014). Carbon Nanocages: A New Support Material for Pt Catalyst with Remarkably High Durability. Scientific Reports, 4(4437), 1-11.

[31] Wang, K., Li, Z., Wang, Y., Liu, H., Chen, J., Holmes, J., \& Zhou, H. (2010). Carbon Nanocages with Nanographene Shell for High-rate Lithium Ion Batteries. Journal of Materials Chemistry, 20(43), 9748-9753.

[32] Tan, Y., Xu, C., Chen, G., Liu, Z., Ma, M., Xie, Q., Zheng, N., \& Yao, S. (2013). Synthesis of Ultrathin NitrogenDoped Graphitic Carbon Nanocages as Advanced Electrode Materials for Supercapacitor. Applied Materials \& Interfaces, 5(6), 2241-2248.

[33] Teng, S. J., Wang, X. X., Xia, B. Y., \& Wang, J. N. (2010). Preparation of Hollow Carbon Nanocages by IodineAssisted Heat Treatment. Journal of Power Sources, 195(4), 1065-1070.

[34] Ghoreishi, K. B., Asim, N., Ramli, Z. A. C., Emdadi, Z., Yarmo, M. A. (2016). Highly Efficient Photocatalytic Degradation of Methylene Blue using Carbonaceous $\mathrm{WO}_{3} / \mathrm{TiO}_{2}$ Composites. Journal of Porous Materials, 23(3), 629-637.

[35] Abdullah, N., Kamarudin, S. K., \& Shyuan, L. K. (2018). Novel Anodic Catalyst Support for Direct Methanol Fuel Cell: Characterizations and Single-Cell Performances. Nanoscale Research Letters, 13, 90.

[36] Yusoff, H. M., Hazwani, N. U., Hassan, N., \& Izwani, F. (2015). Comparison of Sol Gel and Dehydration Magnesium Oxide (MgO) as a Catalyst in Michael Addition Reaction. International Journal of Integrated Engineering, 7(3), 43-50.

[37] Zainoodin, A. M., Kamarudin, S. K., Masdar, M. S., Daud, W. R. W., Mohamad, A. B., \& Sahari, J. (2014). High Power Direct Methanol Fuel Cell With a Porous Carbon Nanofiber Anode Layer. Appl. Energy, 113, 946-954. [38]

Lyu, Z., Yang, L., Xu, D., Zhao, J., Lai, H., Jiang, Y., Wu, Q., Li, Q., \& Wang, X. (2015). Hierarchical Carbon Nanocages As High-rate Anodes For Li- And Na-ion Batteries. Nano Research, 1-9.

[39] Wang, S., Ping, S., \& Wang, X. (2011). Microwave-assisted One-pot Synthesis Of Metal/metal Oxide nanoparticles on graphene and their electrochemical applications. Electrochimica Acta, (56), 3338-3344.

[40] Cheng, Y. \& Jiang, S. P. (2013). Highly Effective And CO-tolerant PtRu Electrocatalysts Supported on Poly (ethyleneimine) Functionalized Carbon Nanotubes For Direct Methanol Fuel Cells. Electrochimica Acta, (99), 124-132.

[41] Antolini, E., \& Cardellini, F. (2001). Formation of Carbon Supported Pt-Ru Alloys: An XRD Analysis. Journal of Alloys and Compounds, 315(1-2), 118-122.

[42] Yahya, N., Kamarudin, S. K., Karim, N. A., \& Masdar, M. S. (2017). Preliminary Study on Pd-Based Binary Catalysts Supported with Carbon Nanofiber for the Electrooxidation of Glycerol. Malaysian Journal of Analytical Sciences, 21(3), 700-708.

[43] Ma, Y., \& Hu, Z. (2005). A Practical Route To The Production of Carbon Nanocages. Carbon, (43), 1667-1672. [44]

Wang, S., Jiang, S. P., \& Wang, X. (2011). Microwave-assisted One-pot Synthesis of Metal/Metal Oxide Nanoparticles on Graphene and their Electrochemical Applications. Electrochimica Acta, 56(9), 3338-3344.

[45] Nassr, A. B. A. A., \& Bron, M. (2013). Microwave-Assisted Ethanol Reduction as a New Method for the Preparation of Highly Active and Stable CNT-Supported Pt-Ru Electrocatalysts for Methanol Oxidation. ChemCatChem, 5(6), 1472-1480.

[46] Li, Z., Jaroniec, M., Papakonstantinou, P., Tobin, J. M., Vohrer, U., Kumar, S., Attard, G., \& Holmes, J. D. (2007). Supercritical Fluid Growth of Porous Carbon Nanocages. Chemistry of Materials, 19(13), 3349-3354.

[47] Ibrahim, S. A., Anwar, M. K., Ainuddin, A. R., Hariri, A., Rus, A. Z. M., Kamdi, Z., Yunos, M. Z., Harun, Z. (2019). Synthesis and Characterization of Visible Light Active $\mathrm{Fe}_{-} \mathrm{TiO}_{2}$ using Hydrothermal Method. International Journal of Integrated Engineering, 11(5), 80-85.

[48] Shi, M., Zhang, W., Zhao, W., Chu, Y., \& Ma, C. (2014). Reduced Graphene Oxide-supported Tungsten Carbide Modified With Ultralow-platinum And Ruthenium-loading For Methanol Oxidation. Electrochimica Acta, (143), 222-231.

[49] Yahya, N., Kamarudin, S. K., Karim, N. A., Basri, S., \& Zanoodin, A. M. (2019). Nanostructured Pd-Based Electrocatalyst and Membrane Electrode Assembly Behavior in a Passive Direct Glycerol Fuel Cell. Nanoscale Research Letters, 14, 52.

[50] Nair, A. A. S., Sundara, R., \& Anitha, N. (2015). Hydrogen Storage Performance of Palladium Nanoparticles Decorated Graphitic Carbon Nitride. International Journal of Hydrogen Energy, 40(8), 3259-3267.

[51] Bagheri, S., Julkapli, N. M., \& Hamid, S. B. A. (2014). Titanium Dioxide as a Catalyst Support in Heterogeneous Catalysis. The Scientific World Journal, 2014, 727496, 21.

[52] Łukaszewski, M., Soszko, M., \& Czerwiński, A. (2016). Electrochemical Methods of Real Surface Area Determination of Noble Metal Electrodes-an Overview. International Journal of Electrochemical Science, 11, 4442-4469.

[53] Tang, Y., Yuan, W., Pan, M., Tang, B., Li, Z., \& Wan, Z. (2010). Effects Of Structural Aspects On The Performance Of a Passive Air-breathing Direct Methanol Fuel Cell. Journal of Power Sources, 195(17), 5628- 
5636.

[54] Shimizu, T., Momma, T., Mohamedi, M, Osaka, T., \& Sarangapani, S. (2004). Design And Fabrication Of pumpless Small Direct Methanol Fuel Cells For Portable Applications. Journal of Power Sources, 137(2), 277283.

[55] Hashim, N., Kamarudin, S. K., \& Daud, W R W (2009). Design, Fabrication And Testing of a PMMA-based Passive Single-Cell And a Multi-cell Stack Micro-DMFC. International Journal of Hydrogen Energy, 34(19), 8263-8269. 